\title{
PELATIHAN PEMBINAAN KEBUGARAN JASMANI PESERTA EKSTRAKURIKULER OLAHRAGA
}

\author{
Imam Mahfud ${ }^{1}$, Aditya Gumantan ${ }^{2}$, Reza Adhi Nugroho ${ }^{3}$ \\ Universitas Teknokrat Indonesia ${ }^{1,2,3}$ \\ imam_mahfud@teknokrat.ac.id ${ }^{1}$,aditya.gumantan@teknokrat.ac.id ${ }^{2}$, \\ reza.adhi.nugroho@teknokrat.ac.id ${ }^{3}$
}

\begin{abstract}
Abstrak
Kegiatan pengabdian kepada masyarakat ini bertujuan untuk memberikan pengetahuan kepada siswa peserta ekstrakurikuler olahraga tentang pembinaan kebugaran jasmani, bentuk tes kebugaran jasmani, dan bentuk latihan pembinaan kebugaran jasmani. Kegiatan pengabdian ini dilaksanakan pada ekstrakurikuler olahraga di SMA Negeri 1 Pringsewu sebagai mitra kegiatan. Berdasarkan hasil kegiatan yang dilaksanakan menunjukkan bahwa, 1) peserta ekstrakurikuler olahraga mengetahui aspek-aspek kebugaran jasmani, 2) peserta ekstrakurikuler olahraga dapat melaksanakan tes kebugaran jasmani. 3) peserta ekstrakurikuler olahraga dapat menyusun menu latihan kebugaran jasmani. Proses monitoring dan evaluasi yang dilaksanakan pada kegiatan ini dilaksanakan dengan pre test dan post test terkait dengan pengetahuan siswa tentang aspek kebugaran jasmani, tes kebugaran, dan menu latihan kebugaransebelum dan setelah kegiatan dilaksanakan.Berdasarkan hasil pre test dan post test yang dilaksanakan didapatkan hasil rata-rata hasil pretest 58,2 dan hasil post test 79,2. Berdasarkan hasil tersebut bahwa terdapat peningkatan pengetahuan siswa setelah dilaksanakan pelatihan pembinaan kebugaran jasmani pada peserta ekstrakurikuler olahraga SMA Negeri 1 Pringsewu.
\end{abstract}

Kata kunci:Pelatihan, pembinaan, Kebugaran Jasmani, ekstrakurikuler

\begin{abstract}
This community service activity aims to provide knowledge to students participating in sports extracurricular activities about physical fitness coaching, forms of physical fitness tests, and forms of physical fitness coaching training. This service activity was carried out in sports extracurricular activities at SMA Negeri 1 Pringsewu as an activity partner. Based on the results of the activities carried out, it shows that, 1) sports extracurricular participants know the aspects of physical fitness, 2) sports extracurricular participants can carry out physical fitness tests. 3) sports extracurricular participants can compile a physical fitness exercise menu. The monitoring and evaluation process carried out in this activity is carried out with a pre-test and post-test related to students' knowledge of aspects of physical fitness, fitness tests, and fitness training menus before and after the activity is carried out. Based on the results of the pre-test and post-test that were carried out, the average pretest result was 58.2 and the post-test result was 79.2. Based on these results, there is an increase in student knowledge after physical fitness coaching training for extracurricular sports participants at SMA Negeri 1 Pringsewu.
\end{abstract}

Keywords:training, coaching, physical fitness, extracurricular activities 


\section{WAHANA DEDIKASI}

Artikel disetujui tanggal:26-04-2020

Corresponden Author:Imam Mahfud e-mail:imam_mahfud@teknokrat.ac.id

DOI: http://dx.doi.org/10.31851/dedikasi.v3i21.5374doi

\section{PENDAHULUAN}

Ekstrakurikuler merupakan kegiatan pendidikan non-pelajaran formal disekolah yang umumnya diluar jam belajar yang sesuai dengan kurikulum. Tujuannya adalah untuk mengembangkan minat dan bakat siswa (Kemendikbud, 2014). Tujuan Ekstrakurikuler olahraga disekolah adalah untuk mengembangkan minat dan bakat siswa dalam bidang olahraga. Selain untuk dapat mengembangkan minat dan bakat siswa esktrakurikuler olahraga juga memfasilitasi siswa untuk berprestasi dalam kecabangan olahraga masingmasing. Untuk mewujudkan hai itu dibutuhkan latihan teknik dan fisik dengan baik.

Observasi yang dilaksanakan pada SMA Negeri 1 Pringsewu yaitu dengan pembina ekstrakurikuler olahraga bahwa proses latihan yang dilaksanakan sudah berjalan sesuai dengan jadwal tetapi kegiatan yang dilaksanakan berjalan kurang maksimal. Tolak ukur ini didapatkan berdasarkan hasil tes kebugaran jasmani pada peserta ekstrakurikuler olahraga masih banyak siswa yang tingkat kebugarannya berada pada tahap kurang. Setelah dilaksanakan wawancara kepada beberapa siswa peserta ekstrakurikuler olahraga didapatkan bahwa siswa kurang memahami pentingnya untuk menjaga kebugaran jasmani. Selama ini siswa hanya mengandalkan latihan yang dijalankan disekolah selama 3 kali dalam seminggu. Seharusnya siswa tetap menjaga kondisi dengan latihan kebugaran dirumah sesuai dengan porsi masing-masing. Akan tetapi tidak semua siswa melaksanakan itu, karena mereka beranggapan bahwa latihan disekolah telah cukup dan hal ini juga dikarenakan mereka kurang memahami konsep kebugaran, dan bentuk latihan kebugaran jasmani.

Berdasarkan hal ini siswa masih terbatas pengetahuannya tentang metode latihan kebugaran beserta porsi latihan dan pentingnya latihan untuk tetap menjaga kebugaran jasmani.

Kebugaran jasmani adalah kemampuan untukmelakukan kegiatan sehari-hari tanpa merasakan kelelahan yang berlebihan. Kebugaran jasmani seseorang dipengaruhi oleh beberapa factor yaitu: genetik, jenis kelamin, usia, komposisi tubuh, aktifitas, dan latihan. Oleh karenaitu, kebugaran jasmani dipakai sebagai parameter kesehatan dan alat ukur kekuatan aerobic maksimal dan kebugaran kardiorespirasi seseorang (Gumantan \& Fahrizqi, 2020; Mahfud et al., 2020).

Kebugaran jasmani merupakan bagian dari proses pembinaan kondisi fisik. Kondisi fisik merupakan salah satu unsur utama dalam pembinaan prestasi olahraga. Untuk itu diperlukan pengetahuan yang baik tentang pembinaan dan latihan kondisi fisik. Aktivitasfisik yang dilakukan secara rutin akan mempengaruhi kebugaran jasmani seseorang (Dewi, 2016; Nuryadi et al., 2018)

Prestasi olahraga didapatkan melalui proses pembinaan dan latihan 


\section{W/AHANA DEDIKASI}

yang sistematis dan terukur. Prestasi olahraga tidak terlepas dari unsure kondisi fisik yang baik. Untuk mencapai prestasi tinggi dalam olahraga kompetitif, seorang atlet sangat membutuhkan kondisifisik prima sesuai dengan kebutuhan dan tuntutan cabang olahraga. (Gumantan \& Fahrizqi, 2020; Mansyur, 2016; Yuliandra et al., 2020).

Pentingnya menjaga kebugaran jasmaniatletbukan hanya menjadi tanggung jawab seorang pelatih, tetapi kesadaran atlet untuk kebutuhan dirinya guna mendapatkan prestasi maksimal sangat penting. hal ini dilakukan sebagai kontrol dalam status kondisi kebugaran fisik dan bahan evaluasi pada program latihan seorang pelatih (Purnomo et al., 2019).

Berdasarkan kondisi yang
terjadipada mitra kami akan
melaksanakan pelatihan pembinaan
kebugaran jasmani untuk
ekstrakurikuler olahraga. Kegiatan ini
akan dilaksanakan dengan mitra SMA
Negeri 1 Pringsewu. Dengan kegiatan
ini harapannya siswa mengetahui
pentingnya pembinaan kebugaran
jasmani. Kegiatan ini dilaksanakan
dengan pelatihan dan pendampingan
kepada siswa peserta ekstrakurikuler
olahraga tentang gambaran umum
kebugaran jasmani, aspek-aspek
kebugaran jasmani, bentuk tes
kebugaran jasmani, dan bentuk
latihan kebugaran jasmani.

\section{BAHAN DAN METODE}

\section{MetodePelaksanaan}

Mekanisme dan tahapan yang dilakukan dalam pelaksanaan kegiatan pengabdian ini adalah sebagai berikut:

\section{Penentuan Mitra Kegiatan}

Penentuan mitra kegiatan dilaksanakan dengan kerjasama yang dijalin. Dalam hal ini mitra adalah SMA Negeri 1 Pringsewu. Kegiatan ini dilaksanakan guna menyelesaikan permasalahan yang terjadi pada mitra.

\section{Persiapankegiatan}

Tahap ini dilaksanakan setelah mengetahui permasalahan yang dialami oleh mitra. Persiapan dilakukan dengan menyiapkan segala kebutuhan dalam pelaksanaan program pelatihan yang akan dilaksanakan. Pada tahap ini hal yan dilakukan meliputi: menyiapkan materi kegiatan pelatihan dan sarana serta prasarana pendukung kegiatan

\section{Pelaksanaan Kegiatan}

Pelaksanaan kegiatan dilakukan setelah semua persiapan terkaitmateri dan sarana pendukung terpenuhi. Kegiatan ini dilaksanakan dengan sebelum kegiatan dilakukan dilaksanakan pretest tentang pengetahuan siswa mengenai kebugaran jasmani, tes kebugaran, dan bentuk latihan kebugaran. Pre test ini dilaksanakan untuk dijadikan tolak ukur pemahaman siswa tentang kebugaran dan sebagai data pelatihan yang akan dilaksanakan. Selanjutnya memberikan pelatihan serta pendampingan tentang kebugaran jasmani, tes kebugaran, dan bentuk latihan kebugaran. Setelah pelatihan yang dilaksanakan dilakukan post test untuk mengetahui ketercapaian dan peningkatan siswa setelah menjalani pelatihan dan pendampingan.

\section{Metode Analisis Data}

Metode analisis data yang dilakukan dengan pendekatan 


\section{WAHANA DEDIKASI}

kuantitatif yaitu dengan membandingkan hasil pretest dan post test sebelum dan setelah siswa melaksanakan pelatihan dan pendampingan kebugaran jasmani.Analisis data dilaksanakan dengan menggunakan uji perbedaan rata-rata dengan menggunakan spss-16 untuk mengetahui peningkatan siswa sebelum dan setelah dilakukan kegiatan pelatihan dan pendampingan.

\section{HASIL DAN PEMBAHASAN}

Hasil kegiatan pengabdian ini dengan pelatihan dan pendampingan kebugaran jasmani pada peserta ekstrakurikuler ini memiliki peranan dalam membantu siswa untuk mengetahuiaspek-aspek kebugaran jasmani, bentuk tes kebugaran jasmani, dan bentuk latihan kebugaran jasmani. Hal ini dapat dilihat berdasarkan data rata-rata hasil pretest dan posttest siswa.

Tabel 1. Data Pretest dan Post test

\begin{tabular}{crr} 
No & Pretest & Posttest \\
\hline 1 & 50 & 70 \\
\hline 2 & 65 & 75 \\
\hline 3 & 60 & 80 \\
\hline 4 & 70 & 80 \\
\hline 5 & 75 & 90 \\
\hline 6 & 65 & 75 \\
\hline 7 & 60 & 80 \\
\hline 8 & 50 & 75 \\
\hline 9 & 70 & 85 \\
\hline 10 & 65 & 90 \\
\hline 11 & 60 & 80 \\
\hline 12 & 55 & 75 \\
\hline 13 & 55 & 80 \\
\hline 14 & 50 & 75 \\
\hline 15 & 60 & 85 \\
\hline 16 & 60 & 85 \\
\hline
\end{tabular}

\begin{tabular}{lll}
\hline 17 & 45 & 70 \\
\hline 18 & 65 & 90 \\
\hline 19 & 55 & 70 \\
\hline 20 & 50 & 80 \\
\hline 21 & 55 & 70 \\
\hline 22 & 60 & 85 \\
\hline 23 & 45 & 80 \\
\hline 24 & 65 & 80 \\
\hline 25 & 45 & 75
\end{tabular}

Tabel 2. Rata-rata Hasil Pretest dan Post Test

\begin{tabular}{lcc}
\hline Keterangan & Pre Test & $\begin{array}{c}\text { Post } \\
\text { Test }\end{array}$ \\
\hline Rata-rata & 58,2 & 79,2 \\
\hline Nilai Terendah & 48 & 70 \\
\hline Nilai Tertinggi & 75 & 90 \\
\hline
\end{tabular}

Berdasarkan tabel diatas didapatkan peningkatan yang signifikan sebelum dan setelah dilaksanakan kegiatan pelatihan pembinaan kebugaran jasmani. Hal ini ditandai dengan perolehan nilai rata-rata hasil pre test 58,2 dengan nilai terendah pretest 48 dan pos test 70. Setelah dilaksanakan pelatihan nilai rata-rata meningkat menjadi 79,2 dengan nilai terendah 75 dan tertinggi 90 .

Tabel 3. Hasil uji normalitas

\begin{tabular}{lll}
\hline & Df & Sig. \\
\hline Pretest & 25 & .178 \\
\hline Post test & 25 & .064 \\
\hline
\end{tabular}

Berdasarkan uji normalitas data pretest dan postest didapatkan hasil pretest 0.178 dan post test 0.064 . karena taraf signifikan pretest dan posttest $\geq 0.05$ maka data dikatakan berdistribusi normal. 


\section{WAHANA DEDIKASI}

Tabel. 4. Hasil Uji korelasi

\begin{tabular}{lcc}
\hline & Pretest & Post Test \\
\hline $\begin{array}{l}\text { Pearson } \\
\text { Correlation }\end{array}$ & .617 & .617 \\
\hline Sig. & .001 & .001 \\
\hline $\mathrm{N}$ & 25 & 25 \\
\hline
\end{tabular}

Berdasarkan hasil uji korelasi pretest dan posttest didapatkan taraf signifikan $0.001 \leq 0.05$ dapat dinyatakan bahwa terdapat pengaruh yang signifikan sebelum dan setelah dilaksankan kegiatan pelatihan dan pendampingan kebugaran jasmani pada ekstrakurikuler olahraga SMA Negeri 1 Pringsewu.

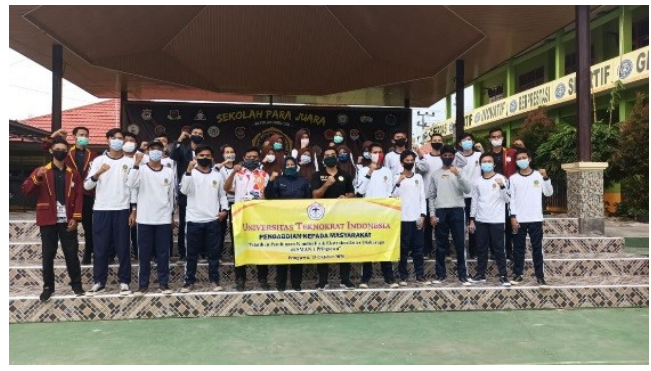

Gambar 1. Kegiatan Pengabdian

\section{KESIMPULAN}

Berdasarkan dari kegiatan pengabdian ini, bahwa pelatihan yang dilakukan ini memberikan dampak positif dalam meningkatkan kompetensi siswa ekstrakurikuler olahraga di SMA Negeri 1 Pringsewu terkait dengan pembinaan kebugaran jasmani.

Hasil yang dicapai dalam kegiatan Pengabdian Kepada Masyarakat iniadalah:
1. Siswa mengetahui tentang konsep dasar kebugaran jasmani

2. Siswa dapat melaksanakan tes kebugaran jasmani

3. Siswa dapat menyusun menu latihan untuk meningkatkan kebugaran jasmani

Program ini akan berjalan semakin baik apabila dapat dilaksanakan secara berkelanjutan, guna pendampingan secara berkelanjutan terhadap pembinaan yang dilakukan

\section{DAFTAR PUSTAKA}

Dewi, U. (2016). Hubungan Kesegaran Jasmani dengan Hasil Belajar Pendidikan Jasmani. Jurnal Pendidikan Olahraga, 5(2), 175-183.

Gumantan, A., \& Fahrizqi, E. B. (2020). Pengaruh Latihan Fartlek dan Cross Country Terhadap Vo2Max Atlet Futsal Universitas Teknokrat Indonesia. Jurnal Sport-Mu Pendidikan Olahraga UM Jember, 1(1), 1-9.

Kemendikbud. (2014). Peraturan Menteri Pendidikan dan Kebudayaan Republik Indonesia Nomor 62 Tahun 2014 tentang Kegiatan Ekstrakurikuler pada Pendidikan Dasar dan Pendidikan Menengah. Kemendikbud.

Mahfud, I., Gumantan, A., \& Fahrizqi, bagus eko. (2020). Analisis IMT (Indeks Massa Tubuh) Atlet UKM Sepakbola Univetsitas Teknokrat Indonesia. Ports Athleticism in Teaching and Recreation on Interdisciplinary Analysis, 3, 9-13. 


\section{VAHANA DEDIKASI}

Mansyur. (2016). Pengaruh Complex

Training Manipulation

Terhadap Peningkatan Power

Otot Tungkai pada Mahasiswa

ProdiI PKO FIK UNY. Jurnal

Olahraga Prestasi, 12(1), 16-

26.

Nuryadi, N., Negara, J. D. K., Juliantine, T., Slamet, S., \& Gumilar, A. (2018). Hubungan Kebugaran Jasmani dengan Kemampuan

Konsentrasi dan Respon Kortisol. Jurnal Pendidikan Jasmani Dan Olahraga, 3(2), $122-128$.

https://doi.org/10.17509/jpjo.v 3i2.12578

Purnomo, E., Gustian, U., \& Puspita, I. D. (2019). Pengaruh program latihan terhadap peningkatan kondisi fisik atlet bolatangan porprov kubu raya. Journal of Sport and Exercise Science, 2(1), 29-33.

Yuliandra, R., Nuhroho, R. A., \& Gumantan, A. (2020). The Effect of Circuit Training Method on Leg Muscle Explosive Power. Journal of Physical Education, Sport, Health and Recreation, 9(3), 157-161.

http://journal.unnes.ac.id/sju/i ndex.php/peshr 